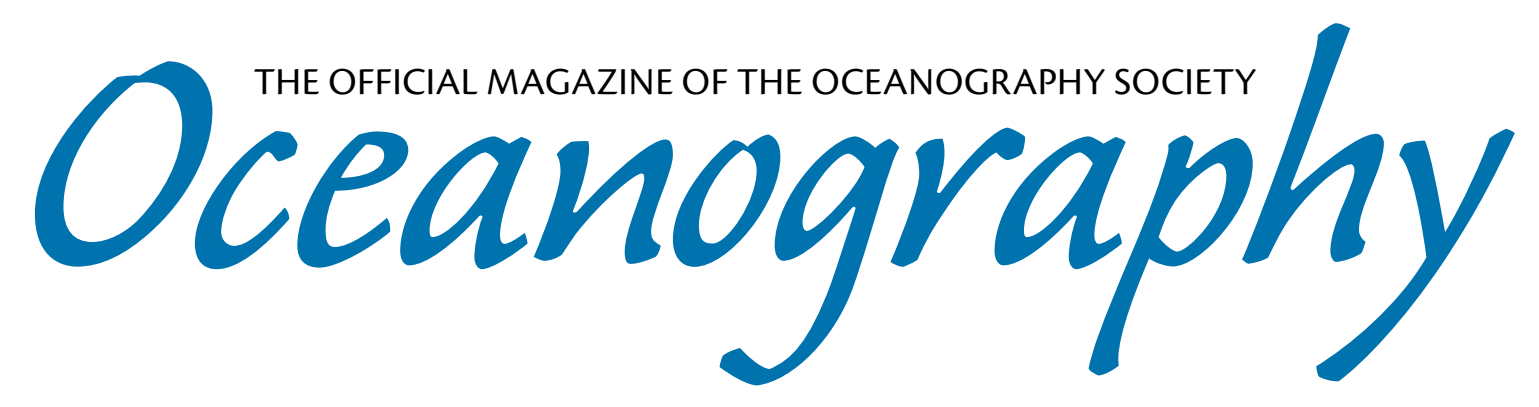

CITATION

Kristoffersen, Y., and J.K. Hall. 2014. Hovercraft as a mobile science platform over sea ice in the Arctic Ocean. Oceanography 27(2):170-179, http://dx.doi.org/10.5670/oceanog.2014.33.

$\mathrm{DOI}$

http://dx.doi.org/10.5670/oceanog.2014.33

COPYRIGHT

This article has been published in Oceanography, Volume 27, Number 2, a quarterly journal of The Oceanography Society. Copyright 2014 by The Oceanography Society. All rights reserved.

USAGE

Permission is granted to copy this article for use in teaching and research. Republication, systematic reproduction, or collective redistribution of any portion of this article by photocopy machine, reposting, or other means is permitted only with the approval of The Oceanography Society. Send all correspondence to: info@tos.org or The Oceanography Society, PO Box 1931, Rockville, MD 20849-1931, USA. 

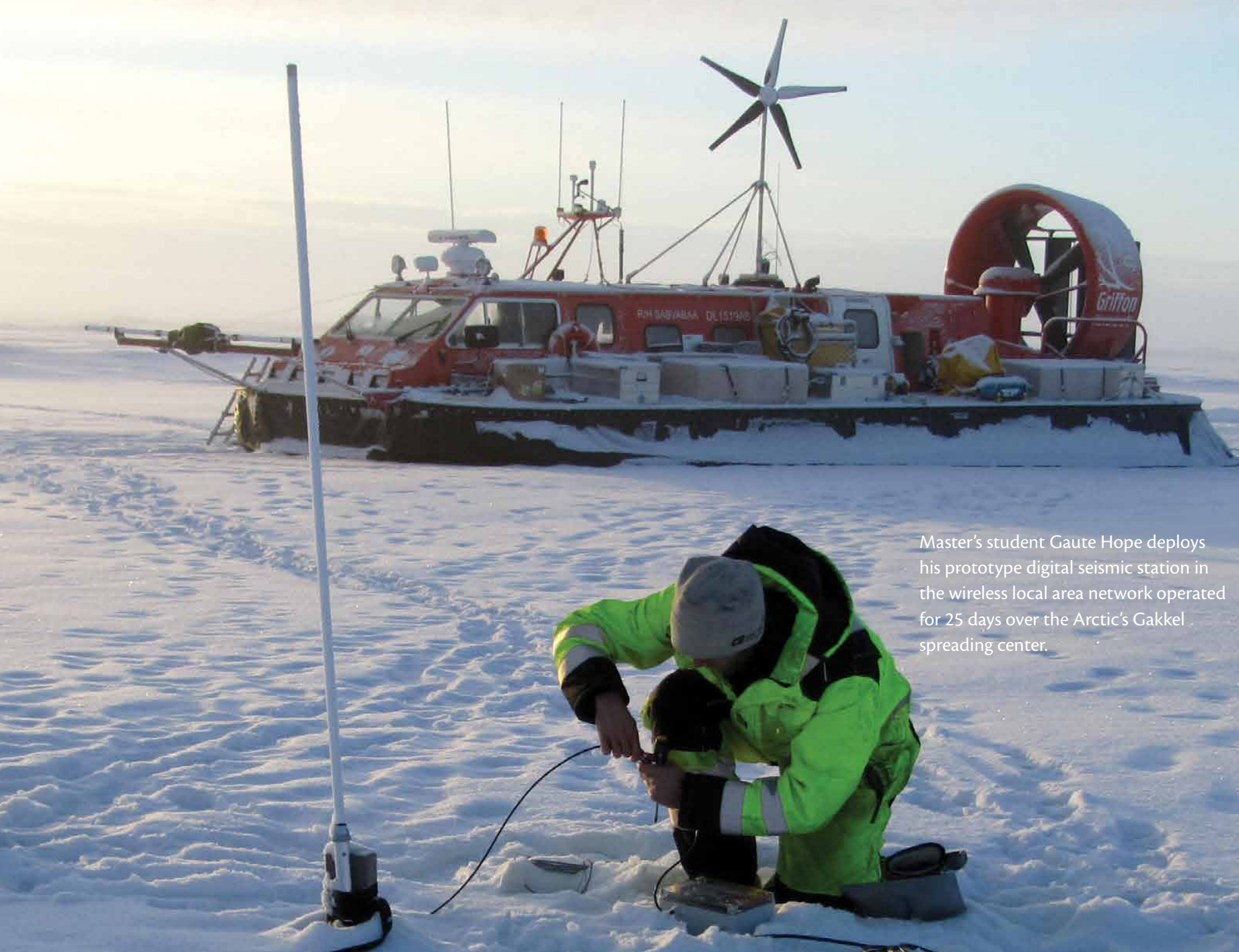

\section{Hovercraft as a Mobile Science Platform Over Sea lce in the Arctic Ocean}


ABSTRACT. Physical sampling of sea ice, the water mass, and subbottom geology in the Arctic Ocean is carried out from icebreakers or temporary ice camps deployed and supported by aircraft. Here, we consider an air-cushion vehicle as an alternative polar research platform to achieve self-contained operation and mobility at low operating cost. We report on five seasons of operating a hovercraft equipped as a polar research vessel with the capability to acquire geological samples and take geophysical and oceanographic measurements along with underway measurements of ice thickness. Long-distance mobility over first-year ice in the Transpolar Drift was put to the test in 2012. Considering only the time spent driving, we maintained a speed of 5-7 knots and had to travel a distance that was 1.3 times the great circle route, with an effective hover height of $0.5 \mathrm{~m}$. Ice surface contrast is critical to efficient hovercraft operations in the polar pack ice. A research hovercraft can operate autonomously, serve as a temporary ice drift station, or operate jointly with an icebreaker. The fuel budget for a full year of daily hovercraft operation is consumed in a single day by a diesel-driven icebreaker.

\section{HISTORICAL BACKGROUND}

The vast expanse of sea ice in the Arctic Ocean presents a formidable challenge to travel and scientific endeavors. Icebreakers are costly to operate, and the use of airplanes is strongly dependent on the absence of surface obstacles as well as seasonal variations in ice surface properties, weather, and visibility. After nearly 40 years of experience with military and commercial air cushion vehicles in cold environments, air cushion vehicle performance on longer trips into the Arctic Ocean remains untested. Although hovercraft can move over water, thin ice, and thick ice with the same relative ease, the polar pack ice is characterized by an intricate network of pressure ridges that challenges hovercraft operations.

The first field use of an air cushion vehicle in the High Arctic may have been operation of a small hovercraft (hover height $0.46 \mathrm{~m}$, payload $350 \mathrm{~kg}$ ) around Camp Century on the
Greenland Ice Sheet in 1964 by the US Army (Abele, 1966). Two years later, in the spring of 1966, Canadian and British governments supported a five-week trial of an SR.N5 hovercraft (hover height $1.4 \mathrm{~m}$, payload 1.6 tons) out of Tuktoyaktuk in the Mackenzie River delta (Cooper and Storr, 1967). The successful tests covered more than $1,000 \mathrm{~km}$ over both sea ice and overland routes, with the longest stretch being $850 \mathrm{~km}$ up the Mackenzie River. A larger SR.N6 hovercraft (payload 3 tons) was subsequently tested from January to March 1968 from Fort Churchill, northern Canada (Fowler, 1976). Considering the strategic importance of the Arctic region, the US Defense Advanced Research Projects Agency (DARPA) initiated an Arctic Surface Effect Vehicle Program in 1970 that tested a modified version of the SR.N5 hovercraft over six months in 1971 out of Point Barrow, Alaska (Kordenbrock and Harry, 1976). These studies focused on the feasibility of crafts with a projected gross weight of 150 to 500 tons, hover heights $>3 \mathrm{~m}$, and payloads of more than 27 tons. High cruise speeds (> 50 knots) were considered necessary for Arctic operations. The military never followed up on construction of a large Arctic hovercraft, but the technology of large air cushion platforms has been applied to hover barges for moving heavy industrial equipment in Alaska and the Canadian Arctic (Dickins et al., 2008; Ireland et al., 2012).

Though the potential for use of hovercraft in support of polar research was recognized early (Mellor, 1963; Fuchs, 1964, 1966; Law, 1965), it was probably first tested on sea and shelf ice at Scott Base in Antarctica in 1977 (Caffin, 1977). Later, the US Antarctic Program operated a small hovercraft (hover height $0.4 \mathrm{~m}$, payload 1.5 ton) to support scientific programs in biology and sea ice research near McMurdo from 1988 to 1990 (Cook, 1989; Dibbern, 1989; http://www.southpolestation.com/ trivia/history/hovercraft.html). In the Arctic Ocean, the first diesel-driven research icebreakers to reach the North Pole, in 1991, brought a small hovercraft (hover height $0.12 \mathrm{~m}$, payload $350 \mathrm{~kg}$ ) to support geophysical work on an ice surface that was littered with melt ponds. The hovercraft was used to tow a $250 \mathrm{~m}$ long seismic snow streamer (Fütterer, 1992). Since 2003, a hovercraft (hover height $0.7 \mathrm{~m}$, payload 2.2 tons) has been used by British Petroleum for logistic support between Prudhoe Bay and the Northstar Island petroleum production facility about $17 \mathrm{~km}$ offshore (Dickins 
et al., 2008). A similar craft, equipped as a polar research platform, has operated out of Svalbard during the summer since 2008, making unsupported science missions of up to three weeks duration and $154 \mathrm{~km}$ into the pack ice (Hall and Kristoffersen, 2009; http://www. polarhovercraft.no). After five seasons of operations, this activity has logged about $4,400 \mathrm{~km}$ of travel over first-year sea ice.

There is a definite need for low-cost polar research platform alternatives capable of supporting a range of smaller science projects that do not require heavy equipment. We consider here field experience during the years 2008-2012 using the research hovercraft Sabvabaa (Hall and Kristoffersen, 2009) and, in particular, the first long distance $\left(81^{\circ} \mathrm{N}\right.$ and $85^{\circ} \mathrm{N}$ ) hovercraft science mission into the Arctic Ocean. The objective of the FRAM-2012 expedition was to carry out marine geological/geophysical work and to measure ice thickness en route.

\section{THE HOVERCRAFT}

The hovercraft R/H Sabvabaa (from the Inuit language, meaning "flows swiftly over it"), built by Griffon Hovercraft Ltd. in Southampton, UK, in 2007, is $11 \mathrm{~m}$ long and $6 \mathrm{~m}$ wide and weighs 5.6 tons (Figure 1). The Griffon 2000TD hovercraft has a double hull of marinegrade aluminum and is designed for autonomous polar operations. Powered by a single water-cooled 440 horsepower diesel engine, it has a stated ground clearance of $0.73 \mathrm{~m}$ and payload capacity of 2.2 tons (http://www.polarhovercraft. no). Sabvabaa can carry a science payload of 400-700 kg in addition to a maximum 2,400 liters of diesel fuel, sufficient for nearly 40 hours at economy speed (20-25 knots over calm water). On a straight northerly course over pack ice, this is equivalent to over four degrees of latitude $(440 \mathrm{~km})$.

The craft is equipped for research in marine geophysics, geology,

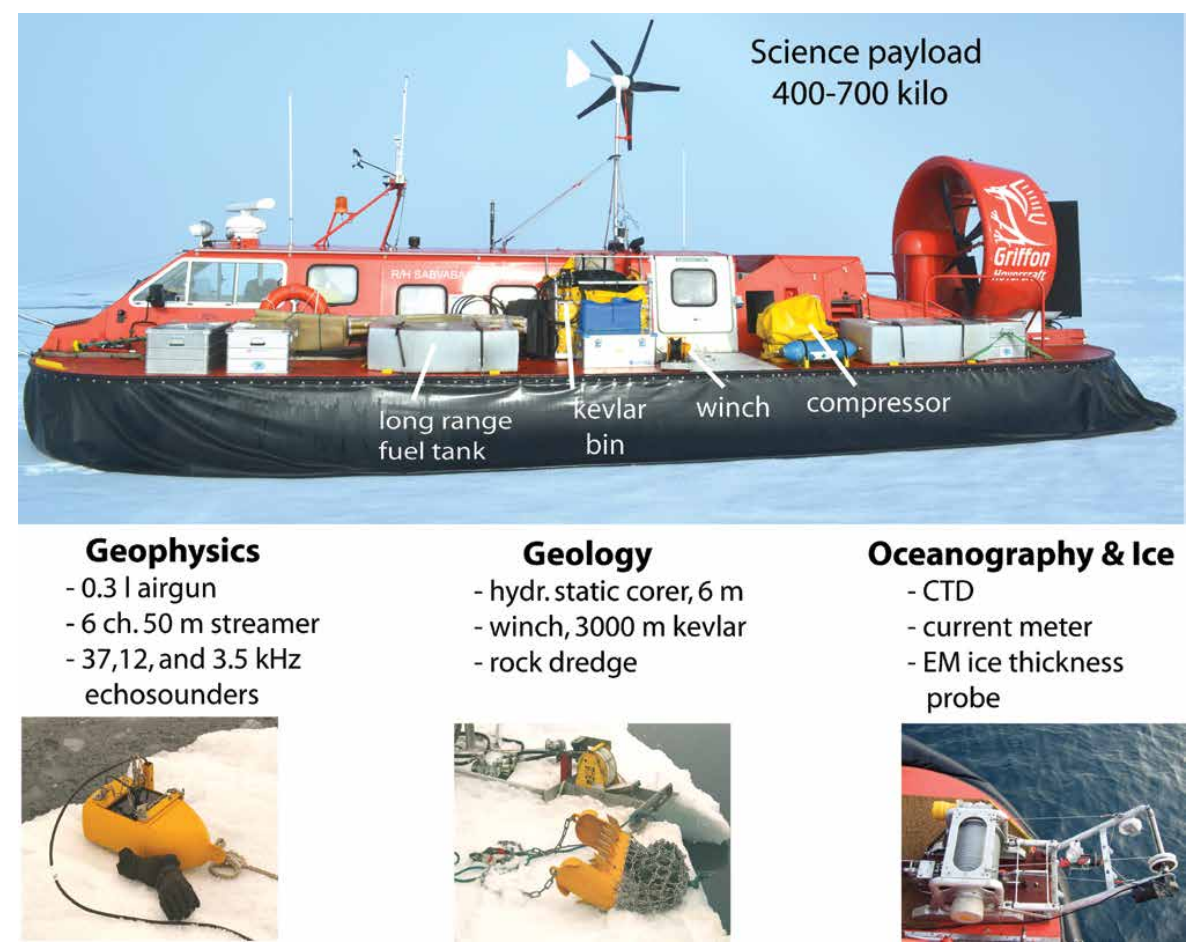

Figure 1. The research hovercraft Sabvabaa and its complement of scientific equipment.

oceanography, and sea ice. It has a crew of two or three scientists (Figures 1 and 2). To minimize weight, all of the scientific equipment is specially designed, with aluminum used extensively, to allow greater fuel-carrying capacity for extended endurance. The equipment includes a 225 bar compressor (Figure 1) for seismic reflection measurements using a 0.3 liter airgun, either in drift mode on the sea ice or towing a six-channel, $50 \mathrm{~m}$ streamer in open leads. Ocean depth is measured by several echosounders $(37,12$, and $3.5 \mathrm{kHz}$ ) suspended below the drifting sea ice. A patented sediment corer ( 3 or $6 \mathrm{~m}$ barrel, ID $9 \mathrm{~cm}$ ) uses hydrostatic pressure to drive the core barrel as a projectile into the seabed (Norwegian patent No. 323149). Sea ice drift provides the peak pullout force so the capacity of the hydraulic winch ( 0.4 ton) is reduced to what is needed to lift any piece of equipment through the water column. Rock dredging also takes advantage of ice drift. The 3,000 $\mathrm{m}$ of $8 \mathrm{~mm}$ thick Kevlar rope (breaking strength 2.8 ton) is collected in a bin attached to the superstructure rather than on a drum to better distribute weight (Figure 1). A Sea-Bird SBE19plus V2 conductivity-temperature-depth (CTD) profiler and an Aanderaa Doppler current meter are also part of the instrumentation package. Water sampling has not been attempted so far. The hovercraft measures ice thickness underway via a front-mounted

Yngve Kristoffersen (yngve.kristoffersen@ geo.uib.no) is Professor Emeritus, Department of Earth Science, University of Bergen, Bergen, Norway, and Nansen Environmental and Remote Sensing Centre, Bergen, Norway. John K. Hall is retired from the Geological Survey of Israel, Jerusalem, Israel. 
electromagnetic transmitter and receiver boom with a sonic altimeter measuring boom height above the ice surface (Haas, 1997). Position information is acquired by a Furuno GP-320B navigation system and logged at 10-second intervals.
A hovercraft leaves hardly any imprint on the ground as the ground pressure is about one-tenth that of an adult person. The broadband noise from a moving Griffon 2000TD hovercraft is less than $87 \mathrm{~dB}$ relating to $20 \mu \mathrm{Pa}$ at distances
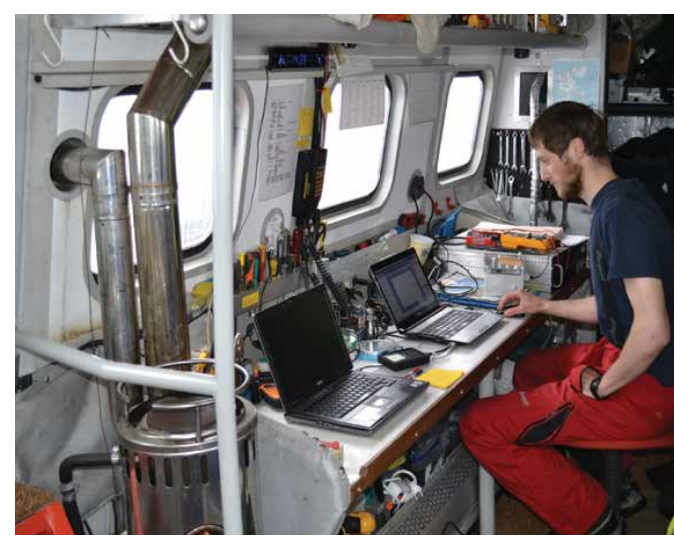

Figure 2. (above) Workbench with data logging systems manned by master's student Gaute Hope. The stove at left in the foreground is used for heating and cooking. (right) Master's student Elin Tronvoll prepares dinner in the kitchen area. beyond $60 \mathrm{~m}$, reaching about $100 \mathrm{~dB}$ up close at a distance of $6.5 \mathrm{~m}$ (Blackwell and Greene, 2005). Noise levels inside the cabin are comparable to levels inside a regular passenger car.

\section{SABVABAA OPERATIONS 2008-2012}

In June 2008, the new hovercraft arrived by ship to its homeport in Longyearbyen, Svalbard. The first two seasons involved a project under the Norwegian contribution to the International Polar Year 2007-2009. Eight pairs of Norwegian high school students were taken on week-long trips to the marginal ice zone to carry out scientific observations akin to what Fridtjof Nansen did during the drift of his ship Fram, but now using modern technology (Ulstein, 2011). The activity took place less than $30 \mathrm{~km}$ from the ice edge (Table 1). During a trip in 2009, 57 CTD stations were taken

Table 1. Summary of hovercraft operations.

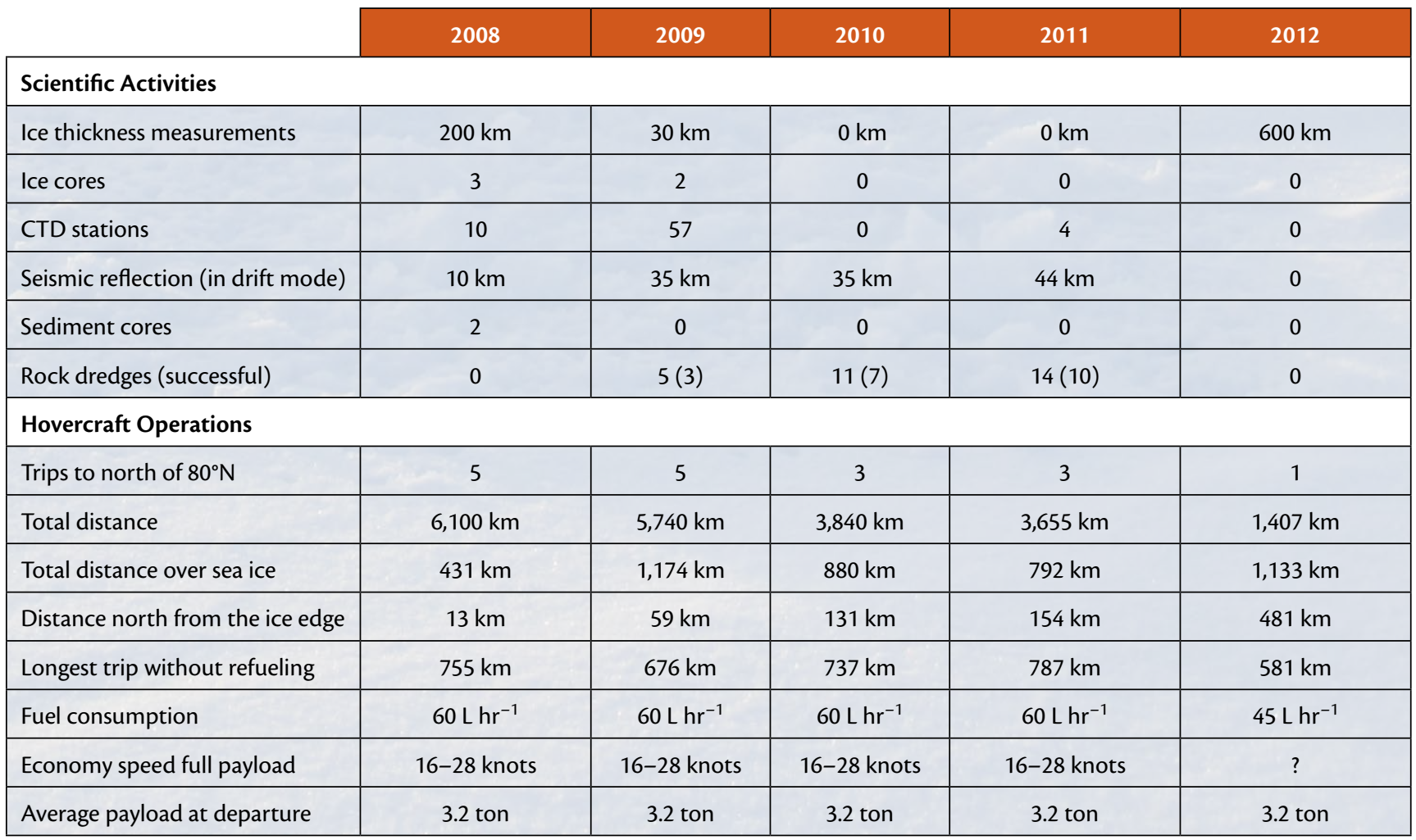


from the sea ice on the shelf north of Svalbard (Figure 3, Table 1). Operations in 2010 and 2011 focused on geological sampling of rock outcrops on the seabed of the Yermak Plateau north of Svalbard in water depths of 700-1,000 m to test interpretations of the origin of this submarine feature (recent work of author Kristoffersen and Yoshihide Ohta (ret.), Norwegian Polar Institute). Individual unsupported cruises from 2010 onward lasted up to three weeks and ventured up to $131 \mathrm{~km}$ north of the ice edge (Table 1 ). More than 3,600 km were covered each season and included about $800 \mathrm{~km}$ of driving in pack ice.

The ultimate opportunity for testing long distance hovercraft mobility over sea ice in the Arctic Ocean came in 2012 during a joint operation with the Swedish icebreaker Oden. The icebreaker mission was to collect geophysical and geological data north of Greenland to support submission of claims extending the outer limits of Danish continental shelf areas beyond 200 nautical miles to the United Nations Convention on the Law of the Sea (http://a76.dk/greenland_uk/north_uk/ gr_n_expeditions_uk/lomrog_2012_uk/ index.html). The hovercraft expedition, named FRAM-2012, was dedicated to geological sampling of the submarine Lomonosov Ridge in water depths of 1,000-2,000 m (Figure 3). The icebreaker supplied the hovercraft with fuel en route to and from its primary work area about $385 \mathrm{~km}$ from the ice edge (Figure 3 ). About halfway to the target area, a short stopover above the Gakkel spreading center was planned to listen for microearthquakes (Figure 3).

Our need for easy access to fuel, as well as safety considerations, make joint operations with icebreakers attractive. Although 24-hour daylight and optimum

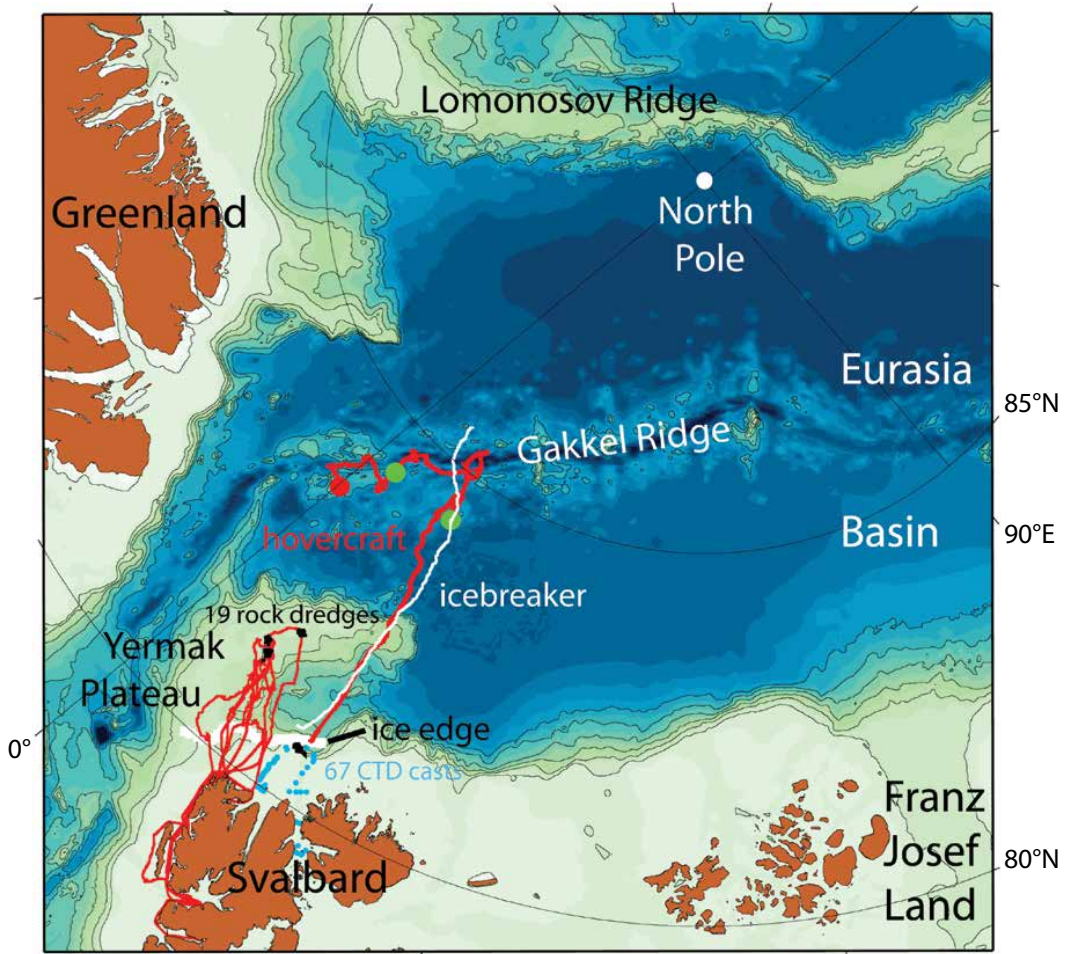

Figure 3. Hovercraft cruises 2010-2012 (red tracks) and track of icebreaker Oden in 2012 (white). Refueling points north of $84^{\circ} \mathrm{N}$ are shown by green dots, and the red dot indicates the rendezvous and pick up by the icebreaker Polarstern. visibility prevail during the early to late spring in the High Arctic, icebreakers generally operate during late summer when sea ice is at a minimum and the typical weather condition is a persistent low and compact cloud cover with reduced visibility. Frequent whiteout conditions and insufficient visibility turned out to be the major impediment to hovercraft progress northward and forced a decision to abort the attempt to reach the primary target over Lomonosov Ridge (Figure 3). Instead, full time was devoted to monitoring earthquake activity at the Gakkel spreading center.

Gakkel Ridge is an ultraslow spreading center where lithospheric plate separation is $<20 \mathrm{~mm} \mathrm{yr}^{-1}$ full rate. The unique aspect of our target section, $3^{\circ}-9^{\circ} \mathrm{E}$, is that ultramafic rocks, not basalts, are abundant within the axial valley (Michael et al., 2003), but the global network of seismographs has not recorded any earthquakes there (Engen et al., 2003). The hovercraft occupied the centroid of a triangular array, up to $5 \mathrm{~km}$ on a side, of four seismic recorders and a broadband seismograph drifting with the sea ice oblique to the rift valley. Three separate deployments were required with the array operating as a wireless local area network over 25 days and recording an average of 10 local seismic events each day (Figure 4; Hope, 2013).

After five weeks of autonomous operation, the hovercraft refueled in early September at Gakkel Ridge from the southbound icebreaker Oden. The intent was for hovercraft instruments to measure ice thickness during the transit south, just as they had on the way north. However, persistent winds from the south and east lasting more than a week set the ice over $52 \mathrm{~km}$ to the northwest (i.e., almost directly opposite 
the long-term drift direction). This massive regional sea ice convergence was accompanied by heavy ridging of firstyear ice, so the welcome opportunity to rendezvous with the German icebreaker Polarstern facilitated a safe journey back to Svalbard, with the hovercraft riding on Polarstern's helo deck.

\section{HOVERCRAFT TRAVEL OVER}

\section{SEA ICE $81^{\circ}-85^{\circ} \mathrm{N}$}

It is worthwhile to compare the transit of the hovercraft and the icebreaker Oden along nearly the same transit from $81^{\circ} \mathrm{N}$ to $85^{\circ} \mathrm{N}$ (Figure 3 ).

Relatively level sea ice ( 2 ridges $/ \mathrm{km}$ ) during the first $37 \mathrm{~km}$ north of the ice edge at $81^{\circ} \mathrm{N}$ enabled the hovercraft to maintain a safe speed over the ground of more than 10 knots (Figure 5a). For the remainder of the trip, the achievable speed was 5-7 knots, and north of $84^{\circ} 15^{\prime} \mathrm{N}$, about 5 knots. The cruise track was straight north, mostly along $15^{\circ} \mathrm{E}$ (Figure 3). Stops were made along the way for meals and overnight stays. At the northern end, progress was interrupted by alternator failure, which forced a five-day drift while waiting for spares to be air dropped. For each track segment, Figure $5 \mathrm{~b}$ shows the ratio between the actual distance traveled and the straight line between end points. This ratio is defined as the trafficability (Hibler and Ackley, 1974). During at least half the transit, this ratio is about 1.2 , and for the remainder about 1.4, except for two trouble spots at the northern end (about $84^{\circ} 18^{\prime} \mathrm{N}$ and $84^{\circ} 40^{\prime} \mathrm{N}$ ) where the ratio is above 2.0. Here, the hovercraft encountered two massive fields of ice rubble, and we had to backtrack to circumvent the problem area.

The position and total distance traveled between the ice edge at $81^{\circ} 03^{\prime} \mathrm{N}$ and $84^{\circ} 40^{\prime} \mathrm{N}$ as logged by the Furuno

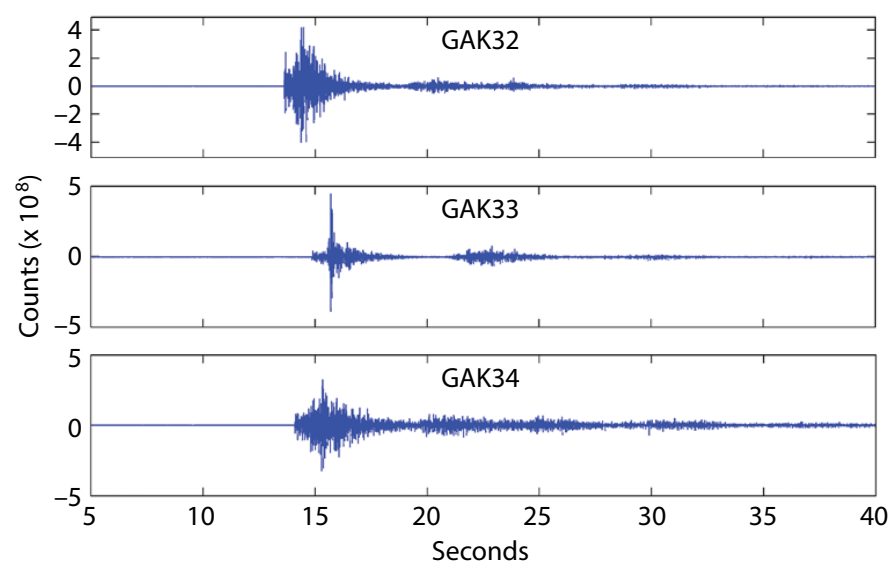

Figure 4. Sample of seismic signals recorded by stations placed in a triangular array, $5 \mathrm{~km}$ on a side, over the Gakkel rift valley.
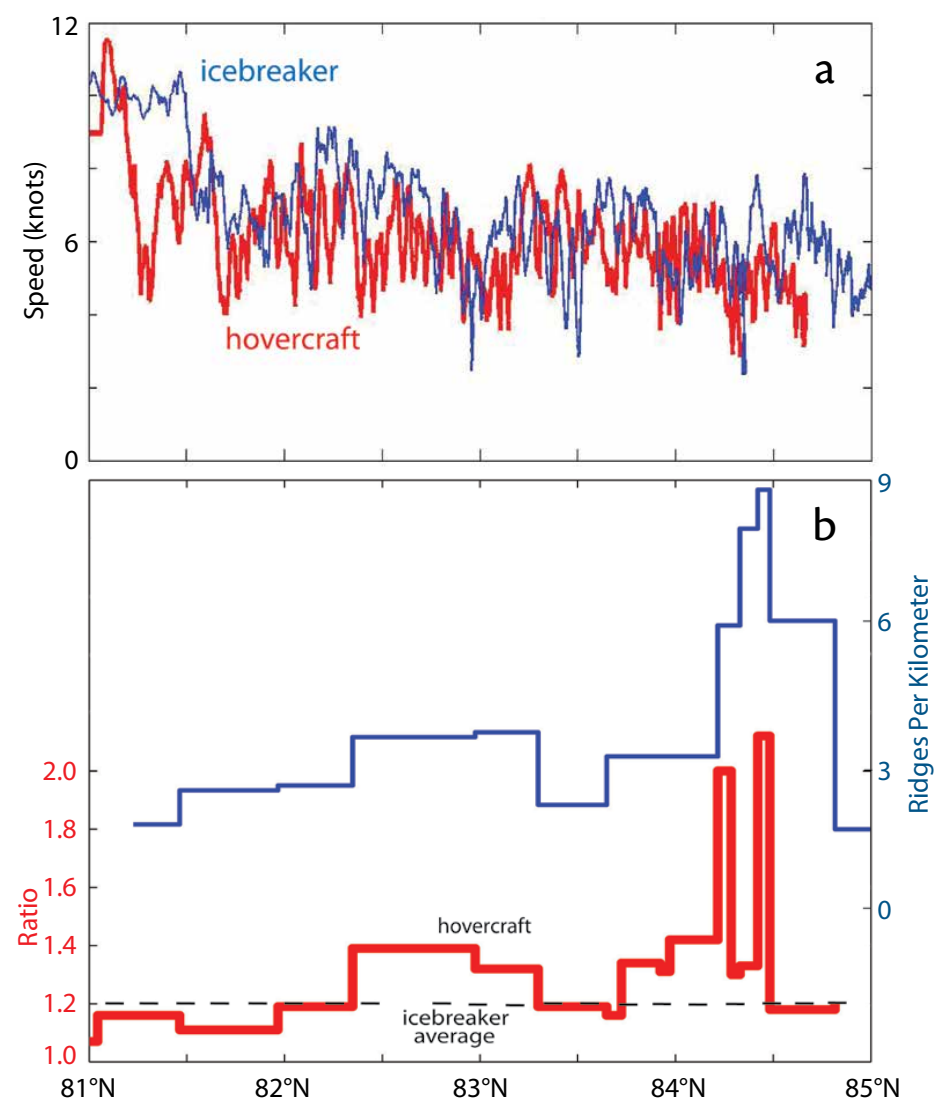

Figure 5. (a) Hovercraft (red) and icebreaker (blue) speed over ground along the transect. The data for the hovercraft include only the time spent driving. Values are running averages over a $4 \mathrm{~km}$ window along the track. (b) Ratio of actual distance traveled relative to great circle distance between start and stop along the transit north (red curve). The dashed horizontal line indicates the ratio for the icebreaker along the same transect. 
navigation system was $518 \mathrm{~km}$, which implies a ratio $\mathrm{D}_{\mathrm{T}} / \mathrm{D}_{\mathrm{SL}}=1.3$ for the total distance traveled relative to a straight line between the end points.

The velocities referred to above only consider the time spent driving. However, total elapsed time consists of three parts: time spent driving, time spent getting out of trouble spots, and time spent for skirt maintenance. As the hovercraft had only one experienced driver, time for sleep is excluded from the calculations, as is time spent waiting for sufficient visibility. From Table 2, the numbers for the $81^{\circ} \mathrm{N}$ to $84^{\circ} \mathrm{N}$ transit are: driving 40.6 hours; time consumed in trouble spots, 6.5 hours; and skirt maintenance, 4 hours. The total is 51 hours, and with all factors included, the effective northward progress becomes 3.5 knots. Between $84^{\circ} \mathrm{N}$ and $84^{\circ} 40^{\prime} \mathrm{N}$, the effective northward progress was reduced to 1.7 knots (Table 2). Fuel consumption for the hovercraft with a total weight of 7-9 tons was about 45 liters per hour over ice during the melt season, and more in the fall when snow on the ice increases friction. Average fuel consumption per degree of northward latitude was 600 liters of diesel, which in this case gives a one-way range of four degrees of latitude.

Icebreaker Oden completed the same northward transit two weeks later.
Under conditions of generally relaxed ice pressure in fields of first-year ice, the icebreaker was able to maintain a speed about 1 knot higher than the hovercraft (Figure 5a). The ratio between distance traveled and a great circle route is 1.2 averaged over the transit. However, the performance of an icebreaker is strongly dependent on general ice field pressure conditions. Diesel-driven icebreakers seek out leads to minimize the fuel consumption required by frequent ramming through large solid ice floes. Under heavy ice pressure, icebreaker progress may be greatly reduced, while this condition would have a less significant effect on hovercraft travel.

\section{DISCUSSION \\ Hovercraft Performance}

The smoothness of the sea ice surface is determined by the response of local and regional ice field rheology to time-varying atmospheric and oceanographic forcing. Ice conditions vary in time and space along any particular geographical transit and are not necessarily representative of ice conditions in the region. Our track along $15^{\circ} \mathrm{E}$ was a random transect through fields of predominantly first-year ice. Table 3 gives the average ice thickness measured along the hovercraft track. The underway ice thickness record may also be used to obtain an estimate of the number of pressure ridges along the traverse. For most of the transit, we encountered three to four ridges per kilometer, and in trouble spots, six to nine ridges per kilometer (Figure 5b).

Hovercraft performance over sea ice depends on hover height and the dimensions of the craft, as well as the pattern of surface obstacles, surface friction, and the wind direction relative to the direction of travel. Visibility and sufficient obstacle definition override all other factors for safe travel. The Griffon 2000TD hovercraft has a nominal hover height of $0.73 \mathrm{~m}$, but the clearance of a loaded craft is no more than $0.5 \mathrm{~m}$. It is possible to climb steps equivalent to the hover height, or traverse higher, wider domelike obstacles, provided there is sufficient momentum. High ice ridges formed by local or regional convergence most often have saddle points, some of which are traversable by our hovercraft. The trafficability number reflects how easy it is to find passable low relief. Large floes of thicker multiyear ice may often be surrounded by a landscape of closely spaced pressure ridges of younger and thinner ice-an environment that is not passable by hovercraft but offers no problem for an icebreaker. Also, the hovercraft pilot sits only $2.5 \mathrm{~m}$ above the surface, and the lack of overview is
Table 2. Summary of hovercraft travel over sea ice.

Table 3. Average ice thickness along hovercraft track.

\begin{tabular}{|l|c|c|c|c|c|c|}
\hline Latitude & $\begin{array}{c}\text { Trafficability } \\
\text { Ratio* }\end{array}$ & $\begin{array}{c}\text { Driving } \\
\text { (hours) }\end{array}$ & $\begin{array}{c}\text { No. Times } \\
\text { Stuck }\end{array}$ & $\begin{array}{c}\text { Stuck } \\
\text { (hours) }\end{array}$ & $\begin{array}{c}\text { Repair } \\
\text { (hours) }\end{array}$ & $\begin{array}{c}\text { Effective } \\
\text { Speed (knots) }\end{array}$ \\
\hline $81^{\circ}-82^{\circ} \mathrm{N}$ & 1.14 & 11 & 1 & 0.75 & 0.75 & 6.6 \\
\hline $82^{\circ}-83^{\circ} \mathrm{N}$ & 1.32 & 15 & 3 & 3 & 0.8 & 2.9 \\
\hline $83^{\circ}-84^{\circ} \mathrm{N}$ & 1.29 & 14 & 6 & 2.7 & 2.4 & 2.6 \\
\hline $84^{\circ}-84^{\circ} 40^{\prime} \mathrm{N}$ & 1.54 & 31 & $5^{*}$ & $5^{*}$ & 7.5 & 1.7 \\
\hline
\end{tabular}

*28 July event excluded (stuck 15 hours)

*The trafficability ratio indicates ease of finding passable low relief in ice ridges.

\begin{tabular}{|c|c|}
\hline $\begin{array}{c}\text { Latitude } \\
\text { Range }\end{array}$ & $\begin{array}{c}\text { Ice } \\
\text { Thickness }\end{array}$ \\
\hline $81^{\circ}-82^{\circ} \mathrm{N}$ & $1.0 \mathrm{~m}$ \\
\hline $82^{\circ}-83^{\circ} \mathrm{N}$ & $1.1 \mathrm{~m}$ \\
\hline $83^{\circ}-84^{\circ} \mathrm{N}$ & $1.3 \mathrm{~m}$ \\
\hline $84^{\circ}-85^{\circ} \mathrm{N}$ & $1.0 \mathrm{~m}$ \\
\hline
\end{tabular}




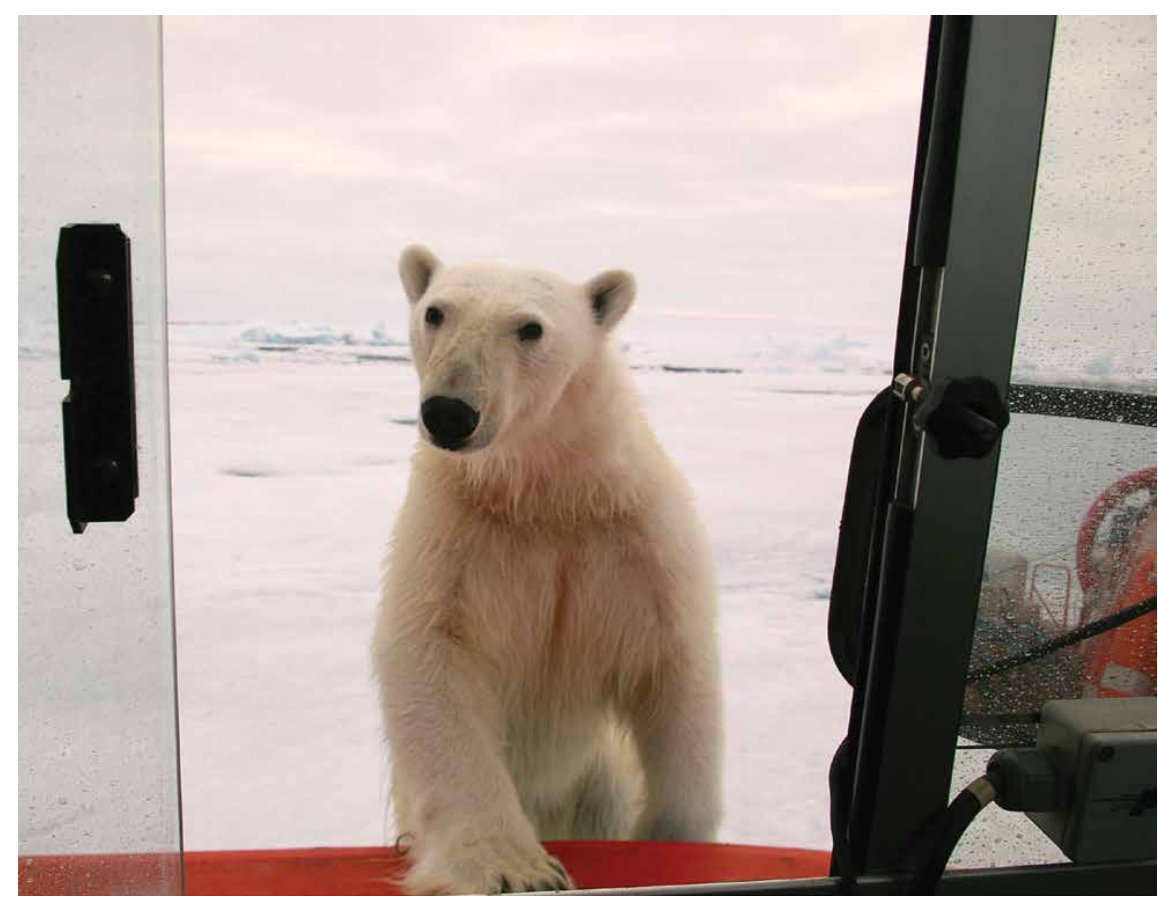

Figure 6. A curious polar bear looks through the driver's side window. Photo credit: Jan Stenløkk

a serious disadvantage for choosing a path in the near field that also represents the best choice farther ahead. Living on the ice is part of the hovercraft operation, and visits by curious polar bears are frequent at times (Figure 6). In all instances, the bears leave when the engine is started.

On 16 occasions during the transit from $81^{\circ} \mathrm{N}$ to $84^{\circ} 40^{\prime} \mathrm{N}$, the hovercraft inadvertently lost lift from running up on, or sliding onto, an ice ridge or an ice block, or it got stuck coming out of a melt pond. When the skirt perimeter lost contact with the surface, the air cushion deflated. Lift was regained by building a support wall of ice blocks to contain the air. In the majority of these cases, it took less than one hour to come off, assisted by a portable electric winch mounted on the front or the back of the hovercraft, as needed.

The most critical factor in hovercraft driving over pack ice is the terrain contrast. The surface of a 10/10 sea ice cover (i.e., total coverage) is completely white on an ice ridge that the driver did not see. Figure 7 shows the number of hours per day with sufficient visibility for driving during the FRAM-2012 expedition. On average, we experienced 14 hours of usable visibility per day during the last half of July, 10 hours per day during the first half of August, 4 hours during the second half of August, and only 2.5 hours per day during September. After late September, the rapidly dwindling daylight further limits activity.

\section{Comparison of Estimates of Trafficability}

The hovercraft Sabvabaa had to travel a distance 1.3 times the straight line between destinations within the southwest moving pack ice of the Transpolar Drift. This ratio is less than the projected performance degradation indicated by Kordenbrock and Harry (1976) and more than an order of magnitude lower than theoretical estimates for a hover height of minimum $0.9 \mathrm{~m}$ (Tucker and Taylor, 1989). A major part of the latter discrepancy probably reflects the difficulty of representing pressure ridge

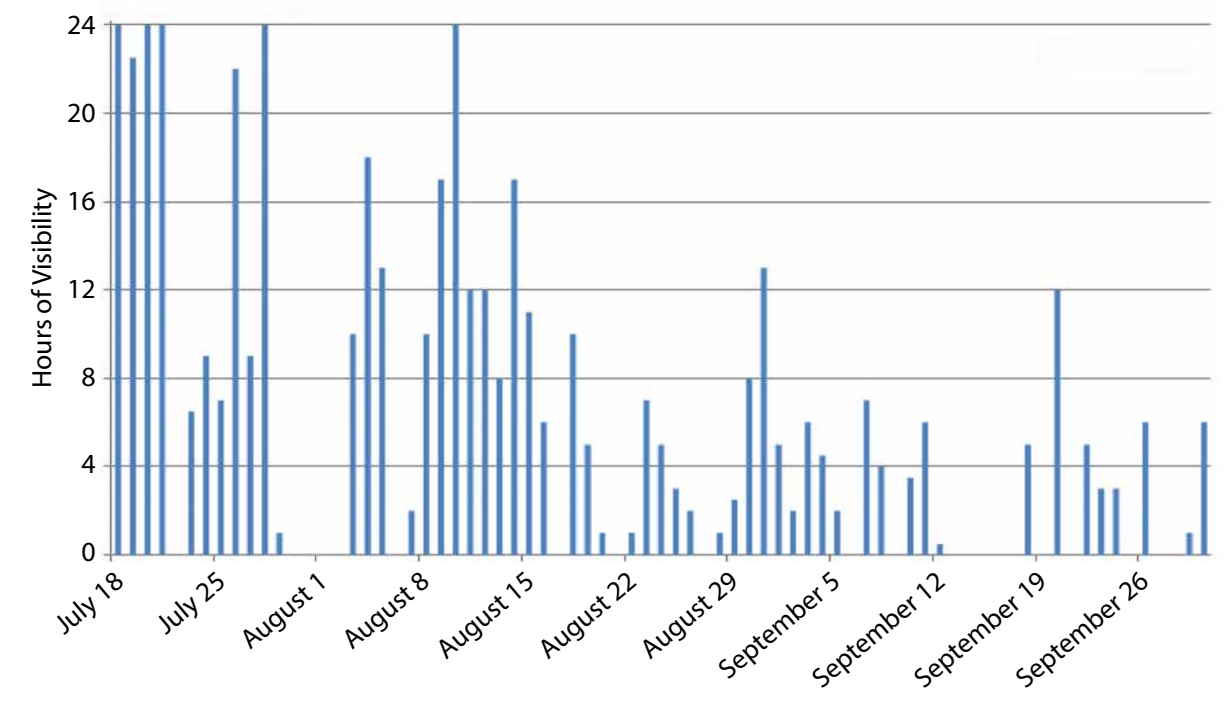

Figure 7. Daily record of hours of visibility sufficient for driving the hovercraft during the FRAM-2012 expedition from the middle of July to the end of September 2012. 
topography from widely spaced laser profiles. Many pressure ridges are linear features of fairly constant height, but in most cases, multiple saddle points are present and readily sighted on approach. Narrow passages appear more abundant than wider ones, and the importance of the relatively narrow width $(6 \mathrm{~m})$ of Sabvabaa was apparent.

In 1968-1969, the British explorer Wally Herbert and his three companions on the Trans-Arctic Expedition traveled with dog sleds from Alaska to Svalbard, covering a distance 1.75 times the great circle route (Herbert, 1970). Attempts to reach the North Pole from Ellesmere Island had to pass over the multiyear ice fields of the Beaufort Gyre. Starting from Ward Hunt Island in 1968, Ralph Plaisted and his snowmobile companions had to drive 1.88 times the direct distance
Paris, or New York to Seattle (1.18). A ratio of 1.3 holds for the highway from Bremerhaven to Berlin (1.29) or Fairbanks to Prudhoe Bay (1.33).

\section{INTERNATIONAL}

\section{COOPERATION}

We collaborated with Christian Haas, York University, Toronto, to develop the capability for underway ice thickness measurements. In 2013, we carried out a mission to test prototype buoys from Laboratoire d'Océanographie de Villefranche for swell attenuation measurements in the marginal ice zone. Both of these activities are well suited for the hovercraft platform. As the track record is further developed, we invite international cooperation. The ultimate hovercraft science mission will be a joint operation with the German research icebreaker Polarstern
AN AIRCUSHION RESEARCH PLATFORM OVER SEA ICE IS FUEL EFFICIENT AND CAN SERVE PROJECTS THAT DO NOT REQUIRE HEAVY EQUIPMENT. THE PLATFORM MAY OPERATE AUTONOMOUSLY OR JOINTLY WITH AN ICEBREAKER, OR IT CAN SERVE AS A TEMPORARY ICE DRIFT STATION.

to get to the North Pole. Later, Ragnar Thorset and his crew of two set out on Ski-Doo snowmobiles from Eureka in 1982 and logged 1.82 times the direct distance (Jørn Fortun, pers. comm., 2013). Incidentally, the ratio is 1.20 for the highway between London and Edinburgh, or Berlin to over Alpha Ridge in the central Arctic Ocean in the fall of 2014. The goal is to reoccupy sites where Mesozoic sediments (Clark, 1974) were recovered from US ice drift station T-3 (Fletcher's Ice Island) in the late 1960s-an area not accessed by research icebreakers so far. Subsequently, the hovercraft and its crew of two will remain over Alpha Ridge to survey a suspected asteroid impact site (Kristoffersen et al., 2008) and drift out toward Fram Strait during the following 12-15 months.

\section{CONCLUSIONS}

Scientific research in the Arctic Ocean faces formidable logistic challenges. We have acquired, outfitted, and tested the concept of using an air cushion platform for multidisciplinary research missions into the pack ice. In the course of five seasons of hovercraft operations, which include about $4,400 \mathrm{~km}$ of track logged north of the ice e.g., we have successfully carried out seismic reflection measurements, geological sampling, CTD casts, and geophysical ice thickness measurements. Transits over first-year sea ice within the Transpolar Drift show that nature appears to offer options for negotiating pressure ridges and making trafficability less dependent on hover height than previously thought. However, progress through pack ice is critically dependent on visibility and terrain contrast. An aircushion research platform over sea ice is fuel efficient and can serve projects that do not require heavy equipment. The platform may operate autonomously or jointly with an icebreaker, or it can serve as a temporary ice drift station. In addition, it is worth noting that a diesel-driven icebreaker advancing through heavy ice in the central Arctic Ocean consumes about 60 tons of fuel per day-an amount sufficient to support daily hovercraft operations for a full year.

\section{ACKNOWLEDGMENTS}

We gratefully acknowledge excellent support in the field to the FRAM-2012 expedition provided by icebreaker Oden through the Swedish Polar Secretariat, 
Stockholm, and the Geological Survey of Greenland and Denmark (GEUS), Copenhagen; the icebreaker Polarstern of the Alfred Wegener Institute for Polar and Marine Research, Bremerhaven; and the $333^{\text {rd }}$ Squadron of the Royal Norwegian Air Force in Andøya, Norway. The effort of Master of Science student Gaute Hope was invaluable to the successful FRAM-2012 field operation, and Ole Meyer, Christian Haas, Ola Johannessen, and Jørn Thiede provided much appreciated advice. Activities during the International Polar Year were supported by the Norwegian Research Council. We thank the Norwegian Petroleum Directorate for having the courage to support our unconventional approach and the first Norwegian scientific expedition into the central Arctic Ocean in 116 years. The hovercraft Sabvabaa is owned by Blodgett-Hall Polar Presence LLC in Delaware, USA. The Nansen Environmental and Remote Sensing Center was the responsible institution for the FRAM-2012 endeavor, and the expedition was carried out under the auspices of the Norwegian Scientific Academy for Polar Research.

\section{REFERENCES}

Abele, G. 1966. Performance Testing of an Air Cushion Vehicle on the Greenland Ice Cap. US Army Cold Regions Research and Engineering Laboratory, Hanover, $\mathrm{NH}$, Special Report 91, 19 pp.

Blackwell, S.B., and C.R. Greene Jr. 2005. Underwater and in-air sounds from a small hovercraft. Journal of the Acoustical Society of America 118:3,646-3,654, http://dx.doi.org/ 10.1121/1.2118347

Caffin, J.M. 1977. First hovercraft tests on ice. Antarctic 8(1):8. Available online at: http://www.antarctic.org.nz/pastissues.html (accessed February 11, 2014).

Clark, D. 1974. Late Mesozoic and Early Cenozoic sediment cores for the Arctic Ocean. Geology 2:41-44, http://dx.doi.org/ 10.1130/0091-7613(1974)2<41:LMAECS> 2.0.CO;2.
Cook, H. 1989. Hovercraft experience in Antarctica. American Institute of Aeronautics and Astronautics Intersociety Advanced Marine Vehicles Conference held Arlington June 5-7, 1989, http://dx.doi.org/10.2514/6.1989-1479.

Cooper, P.F., and J.W. Storr. 1967. Hovercraft trials in the Mackenzie River Delta, 1966. Polar Record 13:433-437, http://dx.doi.org/10.1017/ S0032247400057739.

Dibbern, J.S. 1989. The Introduction of Air Cushion Vehicle Operations at McMurdo Station, Antarctica. Letter Report, US Army Foreign Science and Technology Center, Charlottesville, VA. AST-1150R-100-89, January 3, 1989. 12 pp.

Dickins, D., M. Cox, and J. Thorleifson, 2008. Arctic patrol hovercraft: An initial feasibility study. Proceedings of Ice Tech 2008. Banff, Canada, July 20-23, 2008, Paper No. ICETECH08-115-R0. Available online at: http://www.dfdickins.com/pdf/ICETECH08115-RO.pdf (accessed February 7, 2014).

Engen, Ø., O. Eldholm, and H. Bungum. 2003. The Arctic plate boundary. Journal of Geophysical Research 108, 2075, http://dx.doi.org/10.1029/ 2002JB001809.

Fowler, H.S. 1976. The air cushion vehicle: A possible answer to some Arctic transport problems. Polar Record 18:251-258, http://dx.doi.org/ $10.1017 / \mathrm{S} 0032247400000292$.

Fuchs, V.E. 1964. Polar travel. Pp. 19-20 in Antarctic Research. R. Priestly, R.J. Adie, and G. de Q. Robin, eds, Butterworths, London.

Fuchs, V.E. 1966. Hovercraft in polar regions. Polar Record 13:3-5, http://dx.doi.org/10.1017/ S0032247400055236.

Fütterer, D.K. 1992. ARCTIC 91: The Expedition ARK-VIII/3 of R/V Polarstern in 1991. Berichte zur Polarforschung (Reports on Polar Research), Alfred-Wegener-Institut für Polar- und Meeresforschung, Bremerhaven, Germany, 107:1-267, http://dx.doi.org/10.2312/ BzP_0107_1992.

Haas, C. 1997. Sea-ice thickness measurements using seismic and electromagnetic-inductive techniques. Berichte zur Polarforschung (Reports on Polar Research), Alfred-WegenerInstitut für Polar- und Meeresforschung, Bremerhaven, Germany 223:1-161.

Hall, J.K., and Y. Kristoffersen. 2009. The R/H Sabvabaa: A research hovercraft for marine geophysical work in the most inaccessible area of the Arctic Ocean. The Leading Edge 28:932-935, http://dx.doi.org/10.1190/1.3192839.

Herbert, W. 1970. The first surface crossing of the Arctic Ocean. Geographical Journal 136(4):511-528.

Hibler, W.D. III, and S.F. Ackley. 1974. A sea ice terrain model and its application to surface vehicle trafficability. AIDJEX Bulletin 25:107-126, http://psc.apl.washington.edu/nonwp_projects/ aidjex/files/AIDJEX-25.pdf.

Hope, G. 2013. Exploring the microseismicity of the Gakkel Ridge from Arctic sea ice. MS thesis, Department of Earth Science, University of Bergen, 122 pp.
Ireland, J., D. Turner, and S. Turner. 2012. Leveraging air cushion technology to transport cargo in the Arctic. Paper presented at Arctic Technology Conference, Houston, TX, December 3-5, 2012, Paper OTC23755. Kordenbrock, J.U., and C.W. Harry. 1976. The arctic surface effect vehicle program. Naval Engineers Journal 88:70-83, http://dx.doi.org/ 10.1111/j.1559-3584.1976.tb03813.x.

Kristoffersen, Y., J.K. Hall, K. Hunkins, J. Ardai, B.J. Coakley, J.R. Hopper, and the Healy 2005 seismic team. 2008. Extensive local seabed disturbance, erosion and mass wasting on Alpha Ridge, Central Arctic Ocean: Possible evidence for an extra-terrestrial impact? Norwegian Journal of Geology 88:313-320, http://www.geo. uib.no/hjemmesider/yngve/docs/Asteroid.pdf.

Law, P. 1965. Techniques of living, transport and communication. Pp. 55-80 in Antarctica. T. Hatherton, ed., Methuen, London.

Mellor, M. 1963. Oversnow transport. Cold Regions Science and Engineering, Part III-A4. US Army Cold Regions Research and Engineering Laboratory, Hanover, NH, http://www.dtic.mil/ dtic/tr/fulltext/u2/404778.pdf.

Michael, P.J., C.H. Langmuir, H.J. Dick, J.E. Snow, S.L. Goldstein, D.W. Graham, K. Lehnert, G. Kurras, W. Jokat, R. Mühe, and H.N. Edmonds. 2003. Magmatic and amagmatic seafloor generation at the ultra-slow Gakkel ridge, Arctic Ocean. Nature 423:956-961, http://dx.doi.org/10.1038/nature01704.

Tucker, W.B. III, and S. Taylor. 1989. An Assessment of Trafficability Over Arctic Sea Ice for the Landing Craft, Air Cushion. Cold Regions Research and Engineering Laboratory Report, 85 pp.

Ulstein, K. 2011. Achievements of the education and outreach projects supported by IPY. Pp. 180-190 in International Polar Year: The Norwegian Contribution. O. Orheim and K. Ulstein, eds, Research Council of Norway. 